\title{
The Photo-Protective Activity of Crataegus monogyna Extract Proved by Complementary Mechanisms of Skin Inflammation, Damage of Extracellular Matrix, Cellular Survival and Proliferation Disorders
}

\author{
Brindusa Dumitriu${ }^{1}$, Laura Olariu${ }^{1}$, Manuela Diana Ene ${ }^{1}$, Lenus Zglimbea ${ }^{1}$ and \\ Natalia Rosoiu ${ }^{2 *}$
}

${ }^{1}$ S.C. Biotehnos S.A., Research Department, 3-5 Gorunului Street, Otopeni, Ilfov, 075100 Romania

2"Ovidius" University, Faculty of Medicine, Department of Biochemistry, Constanta, Romania; Academy of Romanian Scientists 54 Splaiul Independentei 050094, Bucharest, Romania

\begin{abstract}
The skin photo-ageing and photo-carcinogenesis are based on cellular mechanisms triggered by UV-radiation, starting with oxidative stress and inflammation, activation of matrix-metalloproteinase (MMP) that increase the structural protein degradation, ending with DNA damage and apoptosis induction. In order to claim the photo-protective activity of an ingredient it's important to explore the main pathways involved in this complex process, highlighting its target action. Our studies are based on a cellular screening of UVA and UVB irradiated keratinocytes (HaCat cell line), focusing on the apoptosis induction, cell cycle sequentiation, metalloproteinase's expression, pro-inflammatory cytokines release and IL $1 \alpha$ as sensitization molecule, as well as the antioxidant capacity of the extract, and acting on catalase and superoxidedismutase activity. The investigation techniques are flow cytometry (cellular parameters fluorescent staining and beadsbased assay for soluble protein detection), zymography and enzymatic activity tests. The Crataegus monogyna extract, with a rich content of pro-antocians, flavones and polyphenolcarboxylic acids, shows a UVA cellular protection and dose dependent inhibition of inflammatory cytokines and MMP 2 and 9 after both UVA and UVB irradiation. All these effects are sustained by a cumulative antioxidant capacity at enzymatic and intracellular oxygen radical level. These findings recommend the phyto-complex for the prevention or therapy of UV-photo damages.
\end{abstract}

Keywords: Crataegus monogyna, UV-radiation, apoptosis, cell cycle, inflammatory cytokines, superoxide anion, catalase, metaloproteinases.

\section{INTRODUCTION}

Ultraviolet exposure of the skin has many detrimental effects, including oxidative stress and inflammation, activation of matrix-metaloproteinases (MMP) that increase the structural protein degradation, DNA damage and apoptosis induction [1]. UV light affects the skin in different ways depending on its wavelength. UVA (320-400 nm) effects are primarily oxidative in nature. UVC $(200-290 \mathrm{~nm})$ hardly ever reaches the surface of the earth. UVB $(290-320 \mathrm{~nm})$ is the most important and is considered the causative agent of many of the effects attributed to UV (8), giving rise to mutations in DNA and modifying the pattern of gene expression [2]. Reactive oxygen species are generated in UV-irradiated human skin, resulting in oxidative damage to lipids, proteins, and DNA [3]. It has been demonstrate that UVA irradiation increased the intracellular levels of hydrogen peroxide $\left(\mathrm{H}_{2} \mathrm{O}_{2}\right)$ and caused oxidative DNA damage, single strand-breaks

*Address corresponding to this author at the "Ovidius" University, Faculty of Medicine, Department of Biochemistry, 1 Aleea Universitatii, Campus CorpB, Constanta, Romania; Academy of Romanian Scientists 54 Splaiul Independentei 050094, Bucharest, Romania; Tel: 0040241605012, 0722737516; Fax: 0040241672 899; E-mail: natalia_rosoiu@yahoo.com and alkali-labile sites. Superoxide anion $\left(\mathrm{O}_{2}{ }^{*}\right)$ was a likely substrate for $\mathrm{H}_{2} \mathrm{O}_{2}$ production since diethyldithiocarbamate (DDC), a superoxide dismutase blocker, decreased the level of intracellular $\mathrm{H}_{2} \mathrm{O}_{2}$. Hydrogen peroxide was shown to play a central role in DNA damage, potentiating the UVA-induced DNA damage [4]. Molecular mechanisms of skin wrinkles are based on the loss of macromolecules from the dermal matrix, collagen being the major component. The level of collagen in normal skin is maintained by the balance between synthesis by dermal fibroblasts and enzymatic degradation. In UV-irradiated skin, the level of matrix metalloproteinases (MMPs) that are important enzymes for the proteolysis of extracellular matrix proteins is elevated long before the visible symptoms of photo aging [5,6]. Among them, MMP-2 (gelatinase A, 72 $\mathrm{kDa}$ ) and MMP-9 (gelatinase $\mathrm{B}, 92 \mathrm{kDa}$ ), secreted as proenzymes, play an important role in degrading type IV collagen. Collagenase/MMP-1 may be activated bylUV-induced cytokine network consisting of IL-1 alpha, IL-1 beta and IL-6, via interrelated autocrine loops contributing to the loss of interstitial collagen in cutaneous photoaging [7]. Inhibition of induction of MMPs has been reported to alleviate UV-induced photoaging by preventing from collagen destruction [8]. 
The keratinocyte is not only a mechanical barrier to the outside but is also a fully immunocompetent cell that can release immunomodulating cytokines such as interleukin IL 1, IL 8, IL 6. The constitutive production of these mediators by keratinocytes both in vivo and in vitro is very low, but it can be dramatically enhanced by UV light. The secretion of these cytokines causes local immunologic and inflammatory reactions following UV irradiation and may be responsible for further systemic effects [9]. UV radiation could be also a tumor initiator by inducing chromosomal alterations and DNA damage, and its promoting activity includes transcriptional modulation of genes involved in tumor promotion [10]. Whereas lower doses of UVB cause DNA mutation leading to tumor initiation, high doses result in irreparable DNA damage causing apoptotic cell formation (sun burn) and eventually cell deletion; formation of sunburn cells is linked to the severity of UVB-induced DNA damage [11]. Cell cycle checkpoints help ensure the accuracy of DNA replication and division, allow progression through the cell-cycle or arrest in response to DNA damage to allow time for DNA repair. The cell-cycle DNA damage checkpoints occur late in $\mathrm{G} 1$, which prevents entry to $S$ phase, and late in G2, which prevents entry to mitosis. Aneuploidy can result from abnormalities in genes regulating chromosome segregation at mitosis as well as from defects in cell-cycle checkpoints that couple replication and mitosis [12]. UVB induces a short delay in G1phase exit and blocks the keratinocytes in the $S$ and G2/M phases of the first cell cycle [13]. UVA exposure induced time-dependent cell cycle arrest in G2/M phase of the cell cycle, beginning at the 4-h time-point, peaking at 8-h time-point and declining thereafter [14]. Considering all these damaging effects of UV radiation it is highlight the need for a complete prevention and treatment of the skin. It has been developed a large panel of topical antioxidants, in order to prevent UVirradiated skin damages and photo-ageing: $\alpha$ tocopherol, L-ascorbic acid, a-lipoic acid, glutathione ethylester, $\mathrm{N}$-acetylcysteine, or natural compound such as flavonoids or triterpenic structures [15-17].

In the present study, we investigated the effects of Crataegus monogyna extract on the UVA and UVB modulated signaling pathways using $\mathrm{HaCaT}$ human keratinocytes as a cellular system model. We focused its effects upon intracellular reactive oxygen species production and the enzymatic system involved in the cellular defense, induction of MMPs, pro-inflammatory cytokines release (IL6 and IL8), as well as IL1 $\alpha$ as a signal molecule for skin irritancy, apoptosis induction and cell cycle progression. We used as positive control the antioxidant N-Acetyl Cysteine.

\section{MATERIALS AND METHODS}

\section{Biological Active Compound}

Crataegus monogyna vegetal extract (Dermo - P), containing pro-antocians $(0.336 \mathrm{~g} / 100 \mathrm{~g}$ extract), flavones $(0.473 \mathrm{~g} / 100 \quad \mathrm{~g}$ extract $)$ and polyphenolcarboxylic acids $(0.833 \mathrm{~g} / 100 \mathrm{~g}$ extract), originally designed in Biotehnos laboratories (Otopeni, Romania).

\section{Cell Culture}

HaCaT standardized cell line - immortalized human normal keratinocyte passages 57-63. Culture medium: Dulbecco's modified eagle's medium nutrient mixture F-12 HAM (DMEM, product number D8437, Sigma) with glucose supplement $(1.35 \mathrm{~g} / \mathrm{L}), 1 \%$ antibiotic / antimycotic $(10,000$ units penicillin, $10 \mathrm{mg}$ streptomycin and $25 \mu \mathrm{g}$ amphotericin B per $\mathrm{ml}$, product number A5955, Sigma), $10 \%$ fetal bovine serum (product number S3113, Biochrom).

\section{The Experimental Design}

Consist of 3 sample series, as following: Series I: unexposed cells (control group); Series II- UVA irradiated cells; Series III: UVB irradiated cells. Experimental data were processed and the results are presented as arithmetic mean of 5 parallel determinations.

Cells were allowed to adhere $24 \mathrm{~h}$, pretreated with the test extracts for $12 \mathrm{~h}$, irradiated with specific doses using a controlled system: Bio-Sun (Vilber-Lourmet) and cultivated for another $16 \mathrm{~h}$ after irradiation. Irradiation doses were established after preliminary tests as following: UVA - 9J/cm2; UVB - 0.02J/cm2, values for which the cells maintain a $50 \%$ survival rate, but a strong pro-apoptotic effect.

\section{Techniques of Analyses}

\section{A) Un-Cellular Methods for the Antioxidant Capacity Screening of the Vegetal Extract}

Total Antioxidant Status (TAS)

Total antioxidant capacity was determined through a colorimetric method based on the reaction between a solution of ABTS and $\mathrm{H}_{2} \mathrm{O}_{2}$ in the presence of peroxidise, forming a stable radical blue-green $\mathrm{ABTS}^{*}$ that can be quantified by measuring absorbance at $\lambda=$ 
$600 \mathrm{~nm}$ with UV/VIS spectrometer (model Lambda 25, Perkin-Elmer). Antioxidants cause a decrease of sample absorbance. (Reagent: TAS (total antioxidant status) kit - RANDOX Laboratories Ltd., United Kingdom) [18].

\section{Antiradicalic Capacity (DPPH REDUCTION METHOD)}

A rapid, simple and inexpensive method to measure antioxidant capacity involves the use of the stable 2,2Diphenyl-1-picrylhydrazyl (DPPH, product number D9132, Sigma) radical. DPPH is widely used to test the ability of compounds to act as free radical scavengers or hydrogen donors, and to evaluate the antioxidant activity. The decrease of DPPH absorbance is measured at $520 \mathrm{~nm}$, after incubation of samples for 30 minutes at $25^{\circ} \mathrm{C}$, and it is proportional with the concentration of free radical scavenger added to DPPH reagent solution. The degree of DPPH radical scavenging activity of the antioxidants was calculated as percentage of inhibition [19, 20].

\section{B) Investigation Methods for "In Vitro" Cytotoxicity}

MTS reduction is a colorimetric method for determining the number of viable cells in proliferation or cytotoxicity assays. The MTS tetrazolium compound (3(4,5-dimetilthiazol-2-yl)-5-(3-carboxymethoxyphenyl)-2$\mathrm{H}$-tetrazoliu) is bioreduced by cells into a colored formazan product that is soluble in tissue culture medium. This conversion is presumably accomplished by NADPH or NADH produced by dehydrogenase enzymes in metabolically active cells. The quantity of formazan product as measured by the absorbance at $490 \mathrm{~nm}$ is directly proportional to the number of living cells in culture. The formazan absorbance at $490 \mathrm{~nm}$ is recorded with a 96-well plate reader (ELISA system, model Tristar LB 941, Berthold Technologies $\mathrm{GmbH}$, Bad Wildbad, Germany). Reagents: CellTiter $96^{\circledR}$ AQueous One Solution Cell Proliferation Assay (Promega) [21, 22]

\section{$\underline{\text { LDH (Lactat Dehydrogenase) }}$}

Release in culture medium is an extensive used marker for in vitro cellular death monitoring. The assay quantitatively measures lactate dehydrogenase (LDH), a stable cytosolic enzyme that is released upon cell lyses (membrane cell disruption following a toxic compound action). LDH released in culture medium reflects in vivo accurate cell viability. Released LDH in culture supernatants is measured with a 30-minute coupled enzymatic assay, which results in conversion of a tetrazolium salt (INT) into a red formazan product. The amount of color formed is proportional to the number of lysed cells. Visible wavelength absorbance data (at 490nm) are collected using a standard 96-well plate reader. Reagents: CytoTox $96{ }^{\circledR}$ Non-Radioactive Cytotoxicity Assay (Promega); equipment: TriStar micro plate reader from Berthold Technologies [23]

\section{C) Cellular Oxidative Stress - Intracellular Activation of Superoxide Anionand Hydrogen Peroxide - Simultaneous Measurement of Intracellular Levels of $\mathrm{H}_{2} \mathrm{O}_{2}$ and $\mathrm{O}_{2}{ }^{-}$- DCFH-DA (Dichlorofluoresceine Diacetat), and HE (Hydroxiethidium) Staining [24, 25]}

DCFH-DA is embedded in lipid hydrophobic region of membrane where hydrolytic enzymes clive the diacetat residues, releasing the membrane permeant configuration which is oxidized in the cytoplasm by the intercellular hydrogen peroxide, producing FITC-A fluorescence $(530 \mathrm{~nm}$ emission). HE permeates the cell membrane and is oxidized by superoxide anion ethidium bromide which tight bond DNA and emits at $620 \mathrm{~nm}$ (PE-A). Hydrogen peroxide and superoxide anion quantities are proportional with the variation of mean fluorescence channel: FITC-A mean - for hydrogen peroxide and PE-A mean - for superoxide anion.

Intracellular Catalase (CAT) and Superoxide Dismutase (SOD) Assessment

To assess the enzyme activity of CAT and SOD, after detach adherent cells with trypsine / EDTA, cells were washed once with cold PBS and suspended in $300 \mu \mathrm{l}$ of Cell Lysis Solution per $1-5 \times 10^{6}$ cells. The suspension was transferred to a $1.5 \mathrm{~mL}$ tube and centrifuge for 5 minutes at $12,000-14,000 \times g$ at $2-8$ ${ }^{\circ} \mathrm{C}$. The supernatant contain extracted cellular catalase and superoxide dismutase. Superoxide dismutase (SOD) is metallo-enzyme that catalyzes the dismutation of superoxide anion into oxygen and hydrogen peroxide. We have been used the spectrometric procedures described by Sigma Aldrich to determine the SOD activity in samples [26] The method is based on the spectrophotometric evaluation (550nm absorbtion spectra) of the inhibition rate of cytochrome $\mathrm{C}$ reduction by competing for the superoxide radical with superoxide dismutase. Catalase (CAT) was assayed according to the method of Aebi [27]. The estimation was done spectrophotometrically measuring the decrease in absorbance at $240 \mathrm{~nm}$. The reaction mixture contained $0.01 \mathrm{M}$ phosphate buffer ( $\mathrm{pH} 7.0$ ), $2 \mathrm{mM} \mathrm{H}_{2} \mathrm{O}_{2}$ and cell lysates. The specific activity of catalase is expressed in terms of units $/ \mathrm{mg}$ protein. A unit is defined as the velocity constant per second. 
D) Flow Cytometry Detection of Soluble Proteins Application on Inflammatory Status Evaluation: Release of Pro-Inflammatory Cytokines IL6 and IL8 and IL1- $\alpha$ as Skin Irritancy Indicator [28, 29]

Human IL1 a Single Plex Flex Set (BD CBA); Human Soluble Protein Master Buffer Kit (BD CBA); BD Cytometric Bead Array (CBA) kit - Human Inflammatory Cytokines kit (BD Pharmingen). BD ${ }^{\mathrm{TM}}$ Cytometric Bead Array (CBA) is a flow cytometry application that allows users to quantify multiple proteins simultaneously. Each bead in the array has unique fluorescence intensity so that beads can be mixed and run simultaneously in a single tube. Each capture bead in the kit has been conjugated with a specific antibody. The detection reagent provided in the kit is a mixture of phycoerythrin (PE)-conjugated antibodies, which provides a fluorescent signal in proportion to the amount of bound analyte (in our particular case IL6, IL8, and IL1- $\alpha$ ). When the capture beads and detector reagent are incubated with an unknown sample containing recognized analytes, sandwich complexes (capture bead + analyte + detection reagent) are formed. These complexes can be measured using flow cytometry to identify particles with fluorescence characteristics of both the bead and the detector. (Detection shown by APC-A / PE-A coordinates) The analysis of the results (standard curve for each cytokine and concentration calculation) is done with FCAP Beads Array software.

\section{E) Flow Cytometry Monitoring of Apoptosis Induction - \% of Live Cells / Necrotic Cells / Early Apoptosis / Late Apoptosis}

Double fluorescent staining (FITC-A and PE) with annexin $V$ (high affinity for phosphatidyl-serine translocated on the outer cellular membrane - the first event of apoptosis) and propidium iodide (bound to DNA when the cellular membrane is disrupted and allow its permeation). Reagents: ANNEXIN V-FITC APOPTOSIS DETECTION kit (BD PHARMINGEN), flow cytometer BD FACS Canto II and Diva 6 software.

\section{F) Cell Cycle Progression}

DNA amount measurements by flow cytometry are possible due to the specific label of DNA with propidium iodide $(\mathrm{PI})$ fluorochrome. $\mathrm{PI}$ is stoichiometrically bound to the base pairs of nucleic acids double bonds and has no specificity for nitrogenous bases. Fluorescence intensity is proportional to cell dye quantity, corresponding with the DNA quantity to which it had been bound. By fluorescence measurement, a distribution histogram is obtained for DNA quantity distributed in the whole cell population. In the distribution histogram for DNA quantity/normal population, the following are plotted: a first peak corresponding to the cell fraction which is found in the phase Go/G1, having a diploid DNA quantity (2N); a second peak, found at a double distance from the first one, which represents the cell fraction in phases $\mathrm{G} 2+\mathrm{M}$, having a tetraploid DNA quantity $(4 \mathrm{~N})$; area included between the two peaks, representing the cells in the synthesis phase $\mathrm{S}$, having an intermediate content of nucleic acids (Figure 5). The isolation and label of the nuclei in cell suspensions is done using Cycle TEST PLUS DNA Reagent (BD PHARMINGEN), data were acquired with FACS CANTO II flow cytometer, and the cell cycle analysis is performed with FCS Express software - DNA cell cycle module.

\section{G) Matrix Metaloproteinases Expression Analysis - Gelatin -Zymography Method}

Considering the correlation of the two proteolytic enzymes (MMP2 and MMP9) with the UV radiation damages and their role in extracellular matrix disruption, we assessed the enzymatic activity of MMP2 and MMP9 based on a gelatine - zymography method described by Herron et al. [30].

In order to evaluate the biocompounds influence on MMP's activity, the culture media samples were separted by SDS-Page using $10 \%$ acryl amide copolymerized with gelatine $(0,1 \mathrm{mg} / \mathrm{ml})$. After electrophoresis, the gel was rinsed twice with $2,5 \%$ Triton X-100 for 30 minute, twice with $\mathrm{H}_{2} \mathrm{O}$ for 15 minute and incubated for $24 \mathrm{~h}$ at $37^{\circ} \mathrm{C}$ in incubation buffer $\left(50 \mathrm{mM}\right.$ Tris- $\mathrm{HCl}, 5 \mathrm{mM} \mathrm{CaCl}_{2}$ and $5 \mu \mathrm{M} \mathrm{ZnCl}$, $\mathrm{pH} 7,5)$. Gelatinase was identified following staining of the gel in 0,25\% Coomasie blue R250 and bleach in $\mathrm{MeOH}$ : Acetic acid : $\mathrm{H}_{2} \mathrm{O}$ (40:10:50, v:v:v). The digested area appeared clear on a blue background, indicating the location of gelatinase. Protein standards were run concurrently and approximate molecular weights were determined. For this study all chemicals were purchased from Sigma - Aldrich and used without further purification.

\section{Statistics}

Experiments were performed in triplicate and mean values was considered. Data were analyzed for statistical significance using a one-way ANOVA followed by Dunnett's t-test to compare treated groups to the appropriate solvent control group. The level of statistical significance used was $\mathrm{P}<0.05$. 


\section{RESULTS AND DISCUSSION}

\section{Preliminary Methods for the Antioxidant Capacity Screening of the Vegetal Extract}

The DPPH • radical scavenger activities and total antioxidant status of $C$. monogyna extracts were assessed at different concentrations, in 3 replicates carried out over 3 days. The resulted regression equations and determination coefficients are listed in Table 1 and Figure 1.

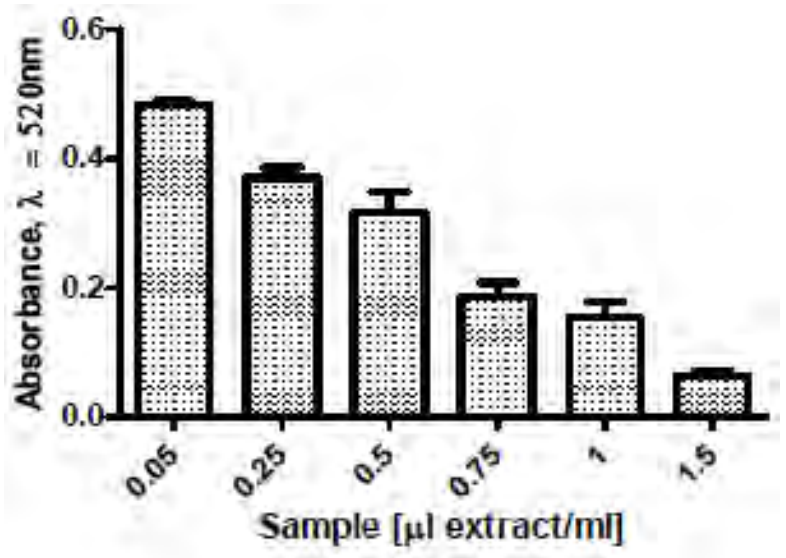

Figure 1: DPPH radical Absorbance decrease after addition of Crataegus monogyna extract (Dermo P), as measured at $520 \mathrm{~nm}$, proving its antioxidant activity.

\section{Cytotoxicity Studies for Crataegus monogyna Extract}

Metabolic activity evaluation and studies on Lactate dehidrogenase release led us to select 1/800 (v:v) dilution as cytotoxicity limit for un-toxic concentrations of $C$. monogyna extract on HaCaT cell line (Figure 2). This dose shows that the bioactive extract is well tolerated by keratinocytes, a very important aspect for a skin care ingredient.

III. Crataegus monogyna Action on Skin Inflammation and Oxidative Stress Induced by UV Radiation

\section{III.1. Protective Effect on Cellular Oxidative Stress: Intracellular Superoxide Anion and Hydrogen Peroxide, Correlated with the Enzymatic Antioxidant System Activation}

The flow cytometry experimental results highlight a functional heterogeneity of keratinocytes as results of irradiation type: the presence of cellular subpopulations with different level of hydrogen peroxide production (Figure 3). The keratinocyte subpopulation with low granularity is characterized only by superoxide anion release, the other with higher granularity present also a higher activation and both oxygen reactive species:

Table 1: Total Antioxidant Capacity (mol/ml), Regression Equations, Linear Determination Coefficients for DPPH. Radical Scavenger Activity and the EC ${ }_{50}$ Values of the Extract of Crataegus monogyna (Dermo P)

\begin{tabular}{|c|c|c|c|c|}
\hline \multirow[b]{2}{*}{ Sample } & \multirow[b]{2}{*}{ TAS $\mathrm{mol} / \mathrm{ml}$} & \multicolumn{3}{|c|}{ DPPH } \\
\hline & & Regression equation & Determination coefficient & $\begin{array}{c}\mathrm{EC}_{50} \\
\boldsymbol{\mu l}\end{array}$ \\
\hline
\end{tabular}

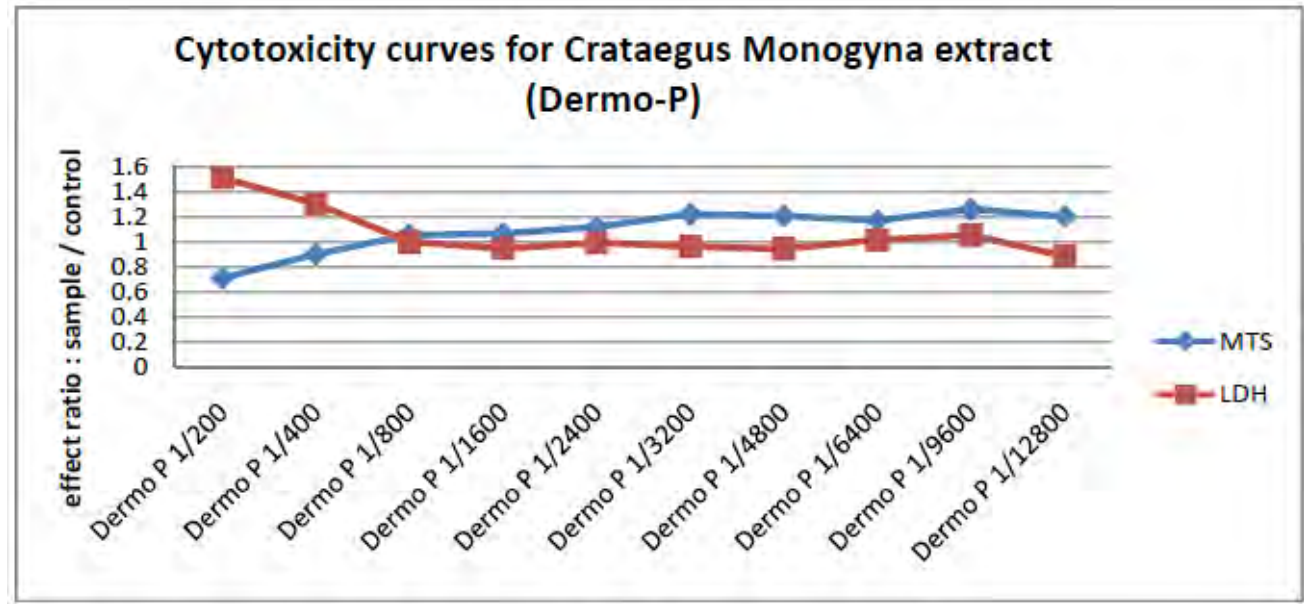

Figure 2: Cytotoxicity curve for Crataegus monogyna extract.

"In order to obtain an accurate cytotoxicity screening we combined the both spectrophotometric methods (MTS reduction and $\mathrm{LDH}$ release), integrating in a single representation the results express as a ratio between the absorbance at 490nm of the sample and the absorbance of the solvent control in the same experimental conditions, for the same technique". 

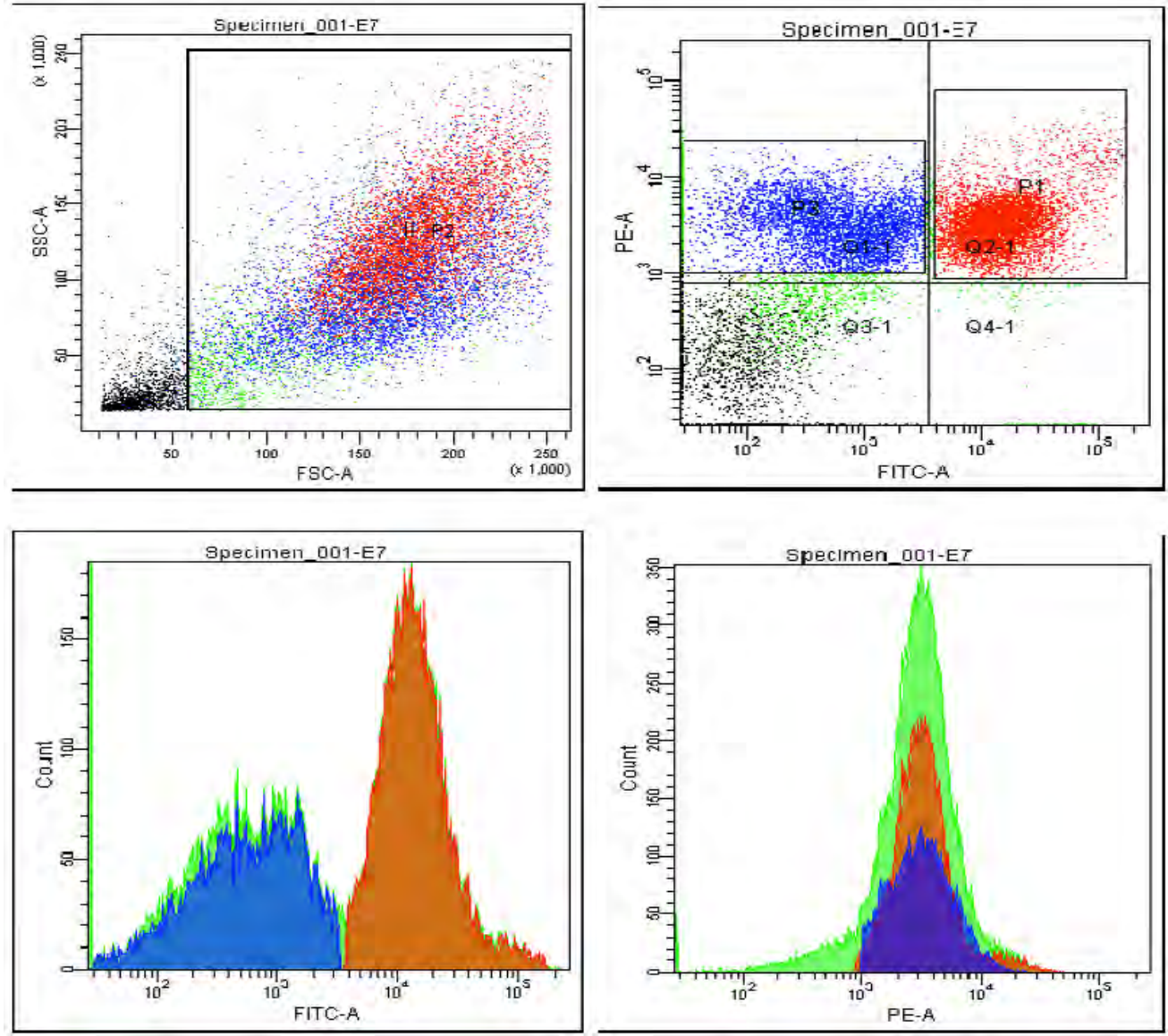

Figure 3: Dot-plot diagrams showing the normal keratinocyte population (FSC /SSC scale) and the responsive subpopulations for cellular activation of hydrogen peroxide (FITC -A), and superoxide anion respectively (PE-A).

hydrogen peroxide and superoxide anion. The flow cytometry multiparametric analyse facilitate the assesment of a differentiated cellular response to UV stimulation, comparing FITC-A fluorescence channel mean for Q1 quadrant (low granularity subpopulation, superoxide anion positive), and FITC-A and PE-A fluorescence channel mean for Q2 quadrant (high granularity subpopulation, superoxide anion and hydrogen peroxide positive) (Table 2). Experimental data reveals a strong effect of $C$. monogyna extract, similar with $\mathrm{N}$-Acetyl-Cysteine, decreasing the intracellular reactive oxigen species release, on both keratinocyte subpopulations. This effect persist at UVA and UVB irradiation, at superoxide anion as well as hydrogen peroxide.

Enzymes such as catalase (CAT) and superoxide dismutase (SOD) play important roles in protecting against free radical damage and are considered the primary antioxidant enzymes involved in direct

Table 2: Fluorescence Channel Mean, Correlated with Intracellular Hydrogen Peroxide and Superoxide Anion

\begin{tabular}{|c|c|c|c|c|c|c|c|c|c|}
\hline \multirow[t]{2}{*}{$\begin{array}{l}\text { Tested } \\
\text { compound }\end{array}$} & \multicolumn{3}{|c|}{$\begin{array}{l}\text { Q2 FITC-A Mean (intracellular } \mathrm{H}_{2} \mathrm{O}_{2} \text { )- } \\
\text { high granularity subpopulation }\end{array}$} & \multicolumn{3}{|c|}{$\begin{array}{l}\text { Q2 PE-A Mean (intracellular } \mathrm{O}_{2}{ }^{-} \text {)-high } \\
\text { granularity subpopulation }\end{array}$} & \multicolumn{3}{|c|}{$\begin{array}{l}\text { Q1 PE-A Mean(intracellular } \mathrm{O}_{2}{ }^{-} \text {)-low } \\
\text { granularity subpopulation }\end{array}$} \\
\hline & $\begin{array}{c}\text { Not } \\
\text { irradiated }\end{array}$ & $\begin{array}{l}\text { UVA } \\
\text { irradiation }\end{array}$ & $\begin{array}{l}\text { UVB } \\
\text { irradiation }\end{array}$ & $\begin{array}{c}\text { Not } \\
\text { irradiated }\end{array}$ & $\begin{array}{l}\text { UVA } \\
\text { irradiation }\end{array}$ & $\begin{array}{l}\text { UVB } \\
\text { irradiation }\end{array}$ & $\begin{array}{l}\text { Not } \\
\text { irradiated }\end{array}$ & $\begin{array}{l}\text { UVA } \\
\text { irradiation }\end{array}$ & $\begin{array}{l}\text { UVB } \\
\text { irradiation }\end{array}$ \\
\hline Cellular control & $5793 \pm 521$ & $10688 \pm 363$ & $32820 \pm 3084$ & $6856 \pm 509$ & $9448 \pm 192$ & $13184 \pm 1102$ & $5243 \pm 142$ & $4448 \pm 79$ & $6644 \pm 513$ \\
\hline Solvent control & $6854 \pm 674$ & $14971 \pm 787$ & $29950 \pm 1548$ & $6715 \pm 39$ & $11609 \pm 732$ & $22406 \pm 1587$ & $4837 \pm 113$ & $3675 \pm 423$ & $5842 \pm 589$ \\
\hline $\begin{array}{l}\text { Crataegus extract } \\
1 / 2000(\mathrm{v}: \mathrm{v})\end{array}$ & $7614 \pm 433$ & $14809 \pm 7405$ & $16665 \pm 1663$ & $8506 \pm 277$ & $12478 \pm 173$ & $10102 \pm 3102$ & $4723 \pm 32$ & $2999 \pm 246$ & $4299 \pm 187$ \\
\hline $\begin{array}{c}\text { Crataegus extract } \\
1 / 4000(\mathrm{v}: \mathrm{v})\end{array}$ & $6431 \pm 548$ & $12921 \pm 646$ & 21678 & $6235 \pm 238$ & $14277 \pm 725$ & $15946 \pm 7321$ & $4925 \pm 189$ & $4266 \pm 337$ & $5054 \pm 444$ \\
\hline $\begin{array}{l}\text { N-Acetyl Cysteine } \\
10 \mathrm{mM}\end{array}$ & $5864 \pm 577$ & $7896 \pm 596$ & 12445 & $6211 \pm 133$ & $6248 \pm 77$ & $7456 \pm 526$ & $5023 \pm 123$ & $2884 \pm 145$ & $4652 \pm 321$ \\
\hline
\end{tabular}


Table 3: Catalase (CAT) and Superoxide Dismutase (SOD) Cellular Activities Modulated by Crataegus monogyna Extract

\begin{tabular}{|c|c|c|c|c|c|c|}
\hline \multirow{2}{*}{$\begin{array}{c}\text { Tested } \\
\text { compound }\end{array}$} & \multicolumn{3}{|c|}{ CAT (nmol/min/mI) } & \multicolumn{3}{c|}{ SOD (U/mI) } \\
\cline { 2 - 7 } & Not irradiated & UVA irradiation & UVB irradiation & Not irradiated & UVA irradiation & UVB irradiation \\
\hline \hline Cellular control & $4.434 \pm 0.02$ & $0.7162 \pm 0.01$ & $0.2494 \pm 0.05$ & $1096.3 \pm 1.3$ & $595 \pm 4.9$ & $1.30 \pm 0.03$ \\
\hline Solvent control & $5.004 \pm 0.12$ & $1.6434 \pm 0.09$ & $0.1248 \pm 0.07$ & $1170.4 \pm 2.5$ & $500 \pm 8.3$ & $1070.24 \pm 3.2$ \\
\hline $\begin{array}{c}\text { Crataegus } \\
\text { monogyna extract } \\
1 / 2000 \text { (v:v) }\end{array}$ & $8.988 \pm 0.26$ & $2.003 \pm 0.11$ & $0.3809 \pm 0.1$ & $1864.4 \pm 3.4$ & $4.35 \pm 0.18$ \\
\hline $\begin{array}{c}\text { Crataegus } \\
\text { monogyna extract } \\
1 / 4000 \text { (v:v) }\end{array}$ & $18.216 \pm 0.4$ & $3.3516 \pm 0.32$ & $0.6732 \pm 0.09$ & $2776.8 \pm 5.1$ & $1323.58 \pm 9.1$ & $5.51 \pm 0.6$ \\
\hline
\end{tabular}

elimination of reactive oxygen species. We assessed their activity (Table 3 ) in order to explain the superoxide anion and hydrogen peroxide intracellular variations induced by $C$. monogyna extract.

C. monogyna extract induce activation of both catalase and peroxidase, highlighting the enzymatic mecanism of its cellular antioxidant action: it acts on enzymes that transforme the damaging oxigen radicals, not directly on reactive oxigen species.

\section{III.2. Effects on Pro-Inflammatory Cytokines IL6 and IL8 and IL1 $\alpha$ as Skin Sensitization Molecule}

C. monogyna extract exerts anti-inflammatory action especially on IL8 release in extracellular medium, one of the main signal protein for triggering the inflammatory response, both after UVA and UVB exposure. (Table 4) IL6 release is blocked only after UVA irradiation, UVB proving to be more aggressive from this point of view. In respect of skin irritancy, release of IL $1 \alpha$ is augmented by C. monogina extract, especially by the higher dose. It is reccomended the use of this extract avoiding direct sun exposure.

\section{Crataegus monogyna Action on Cellular Survival and Proliferation Disorders Induced by UV Radiation}

\section{IV.1. Effects on Apoptosis Induction}

The vegetal extracts effects on apoptotic process induced by UV radiation are presented in Table $\mathbf{5}$ and Figure 4. The comparative analysis of cellular percent of live / necrotic / early apoptotic / late apoptotic cells reveals a slight cellular protection against UVA apoptosis induced by $C$. monogyna extract. UVB is a more aggressive radiation and the components from $C$. monogyna extract are not strong enough to counteract the apoptotic process initiation.

\section{IV.2. Effects on Cell Cycle Progression}

UV radiation induces different effects on cell cycle check-points, depending on the wavelenght. UVA

Table 4: Modulation of Pro-Inflammatory Cytokines IL6, IL8 and IL1 a Release by Crataegus monogyna Extract

\begin{tabular}{|c|c|c|c|c|c|c|c|c|c|}
\hline \multirow{2}{*}{$\begin{array}{c}\text { Tested } \\
\text { compound }\end{array}$} & \multicolumn{3}{|c|}{ IL-1a (ng/ml) } & \multicolumn{3}{|c|}{ IL-6(ng/mI) } & \multicolumn{3}{|c|}{ IL-8(ng/ml) } \\
\hline & $\begin{array}{c}\text { Not } \\
\text { irradiated }\end{array}$ & $\begin{array}{c}\text { UVA } \\
\text { irradiation }\end{array}$ & $\begin{array}{c}\text { UVB } \\
\text { irradiation }\end{array}$ & $\begin{array}{c}\text { Not } \\
\text { irradiated }\end{array}$ & $\begin{array}{c}\text { UVA } \\
\text { irradiation }\end{array}$ & $\begin{array}{c}\text { UVB } \\
\text { irradiation }\end{array}$ & $\begin{array}{c}\text { Not } \\
\text { irradiated }\end{array}$ & $\begin{array}{c}\text { UVA } \\
\text { irradiation }\end{array}$ & $\begin{array}{c}\text { UVB } \\
\text { irradiation }\end{array}$ \\
\hline $\begin{array}{l}\text { Cellular } \\
\text { control }\end{array}$ & $174,5 \pm 7.9$ & $361.0 \pm 3.3$ & $316.6 \pm 4.4$ & $800.3 \pm 145$ & $897.3 \pm 136$ & $4632 \pm 519$ & $6407 \pm 541$ & $898.8 \pm 111$ & $7313 \pm 362$ \\
\hline $\begin{array}{l}\text { Solvent } \\
\text { control }\end{array}$ & $148.5 \pm 35.3$ & $341.5 \pm 5.4$ & $295.4 \pm 5.1$ & $465.1 \pm 57$ & $931.3 \pm 198$ & $4598 \pm 308$ & $3470 \pm 176$ & $857.1 \pm 58$ & $6373 \pm 986$ \\
\hline $\begin{array}{c}\text { Crataegus } \\
\text { monogyna } \\
\text { extract } \\
1 / 2000 \text { (v:v) }\end{array}$ & $219.5 \pm 10.9$ & $431.1 \pm 4.8$ & $356.3 \pm 2.6$ & $825.6 \pm 124$ & $208.9 \pm 12$ & $4818 \pm 411$ & $6329 \pm 768$ & $112.0 \pm 51$ & $6884 \pm 116$ \\
\hline $\begin{array}{c}\text { Crataegus } \\
\text { monogyna } \\
\text { extract } \\
1 / 4000(\mathrm{v}: \mathrm{v})\end{array}$ & $193.6 \pm 8.3$ & $325.9 \pm 3.1$ & $343.2 \pm 4.5$ & $779.7 \pm 138$ & $651.8 \pm 42$ & $4385 \pm 368$ & $4890 \pm 553$ & $330.4 \pm 76$ & $5659 \pm 294$ \\
\hline $\begin{array}{c}\text { N-Acetyl } \\
\text { Cysteine } \\
10 \mathrm{mM}\end{array}$ & $172.6 \pm 10$ & $286.5 \pm 5.8$ & $236.9 \pm 0.6$ & $878.0 \pm 100$ & $207.3 \pm 11$ & $2438 \pm 100$ & $5571 \pm 671$ & $158.0 \pm 10$ & $4888 \pm 99$ \\
\hline
\end{tabular}


Table 5: Cellular Percent of Live / Apoptotic / Necrotic Keratinocites Before / After UV Irradiation, Modulated by Bioactive Extract of Crataegus monogyna

\begin{tabular}{|c|c|c|c|c|c|c|c|c|c|}
\hline \multirow{2}{*}{$\begin{array}{c}\text { Tested } \\
\text { compound }\end{array}$} & \multicolumn{3}{|c|}{ Live cells } & \multicolumn{3}{c|}{ Apoptotic cells } & \multicolumn{3}{c|}{ Necrotic cells } \\
\cline { 2 - 9 } & $\begin{array}{c}\text { Not } \\
\text { irradiated }\end{array}$ & $\begin{array}{c}\text { UVA } \\
\text { irradiation }\end{array}$ & $\begin{array}{c}\text { UVB } \\
\text { irradiation }\end{array}$ & $\begin{array}{c}\text { Not } \\
\text { irradiated }\end{array}$ & $\begin{array}{c}\text { UVA } \\
\text { irradiation }\end{array}$ & $\begin{array}{c}\text { UVB } \\
\text { irradiation }\end{array}$ & $\begin{array}{c}\text { Not } \\
\text { irradiated }\end{array}$ & $\begin{array}{c}\text { UVA } \\
\text { irradiation }\end{array}$ & $\begin{array}{c}\text { UVB } \\
\text { irradiation }\end{array}$ \\
\hline \hline Cellular control & $85.87 \pm 4.90$ & $50.27 \pm 0.32$ & $43.93 \pm 3.20$ & $12.45 \pm 0.40$ & $48.10 \pm 1.91$ & $46.70 \pm 4.25$ & $3.30 \pm 0.30$ & $1.667 \pm 0.11$ & $9.333 \pm 0.29$ \\
\hline Solvent control & $86.67 \pm 3.25$ & $46.93 \pm 0.27$ & $40.03 \pm 1.22$ & $9.7 \pm 1.34$ & $60.73 \pm 2.39$ & $51.90 \pm 0.96$ & $3.63 \pm 0.71$ & $2.367 \pm 0.15$ & $8.033 \pm 0.56$ \\
\hline $\begin{array}{c}\text { Crataegus } \\
\text { monogyna } \\
\text { extract 1/2000 } \\
\text { (v:v) }\end{array}$ & $81.53 \pm 3.36$ & $49.97 \pm 0.48$ & $35.53 \pm 2.30$ & $15.20 \pm 2.78$ & $49.20 \pm 4.94$ & $58.61 \pm 4.99$ & $6.30 \pm 0.86$ & $0.833 \pm 0.037$ & $5.867 \pm 0.23$ \\
\hline $\begin{array}{c}\text { Crataegus } \\
\text { monogyna } \\
\text { extract } \\
1 / 4000 \text { (v:v) }\end{array}$ & $83.00 \pm 2.14$ & $71.15 \pm 0.22$ & $39.23 \pm 1.82$ & $12.77 \pm 1.36$ & $26.62 \pm 3.50$ & $51.81 \pm 7.21$ & $4.23 \pm 0.24$ & $2.233 \pm 0.11$ & $8.967 \pm 0.41$ \\
\hline $\begin{array}{c}\mathrm{N}-\text {-Acetyl } \\
\text { Cysteine 10mM }\end{array}$ & $83.43 \pm 1.15$ & $67.80 \pm 0.10$ & $69.34 \pm 5.08$ & $14.50 \pm 1.00$ & $28.60 \pm 1.00$ & $30.03 \pm 1.02$ & $1.90 \pm 0.10$ & $0.200 \pm 0.01$ & $0.400 \pm 0.05$ \\
\hline
\end{tabular}

A
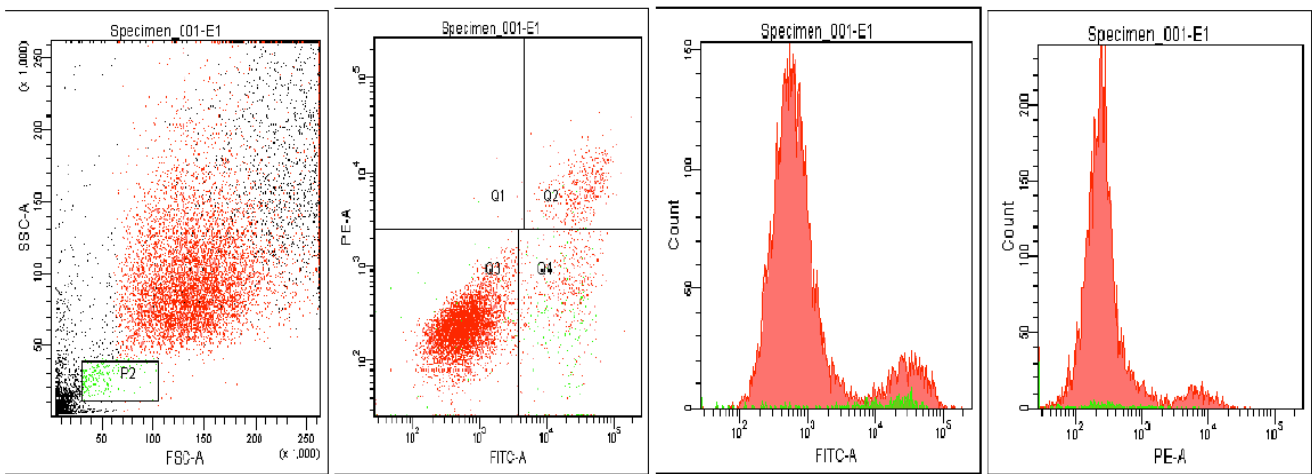

B
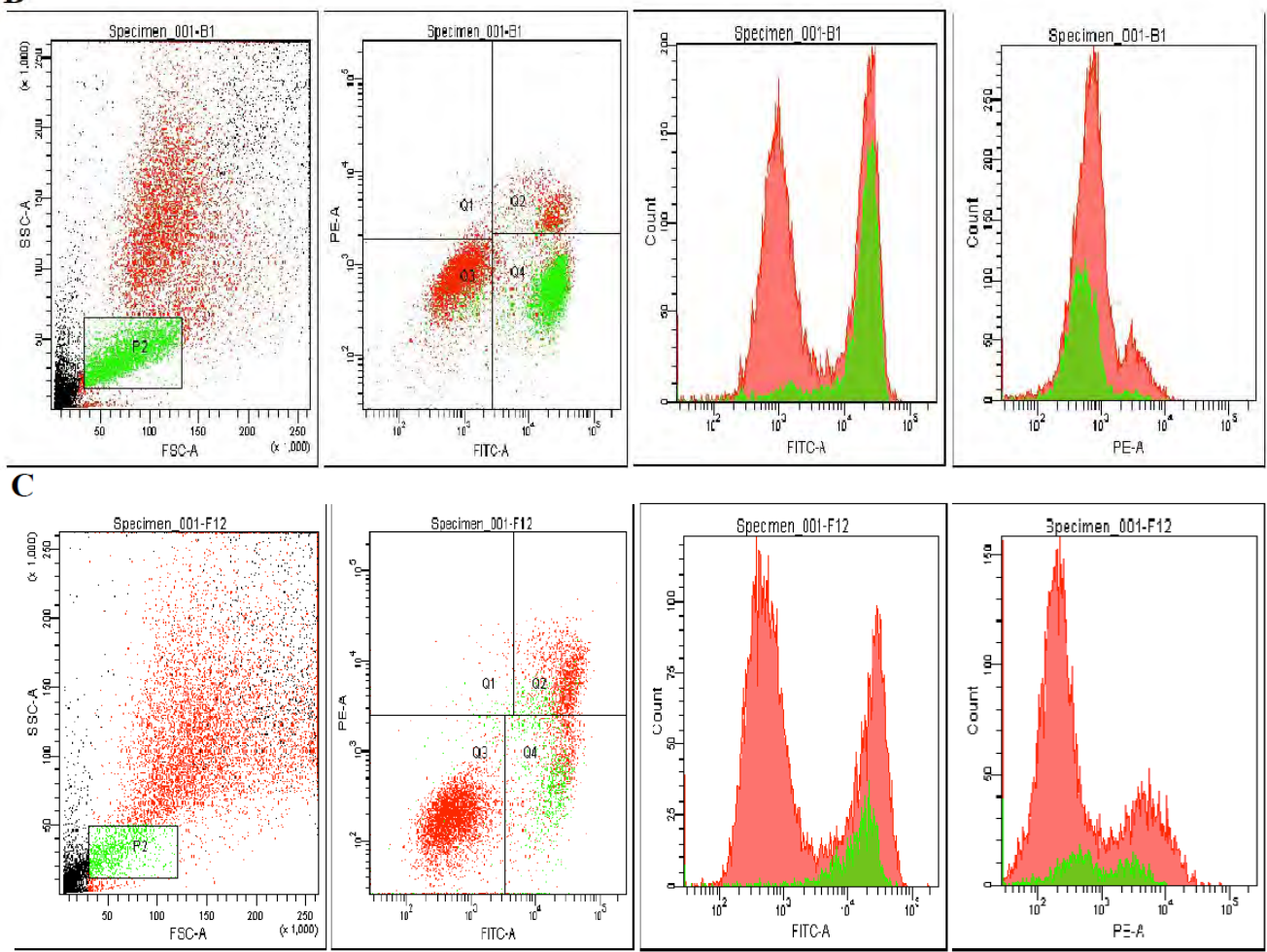

Figure 4: Flow cytometry diagrams showing apoptosis induction by UVA irradiation and Crataegus monogyna extract treatment. A) unirradiated cells, B) Control UVA irradiated cells, C) UVA irradiated cells treated with Crataegus extract (Dermo P). 
A

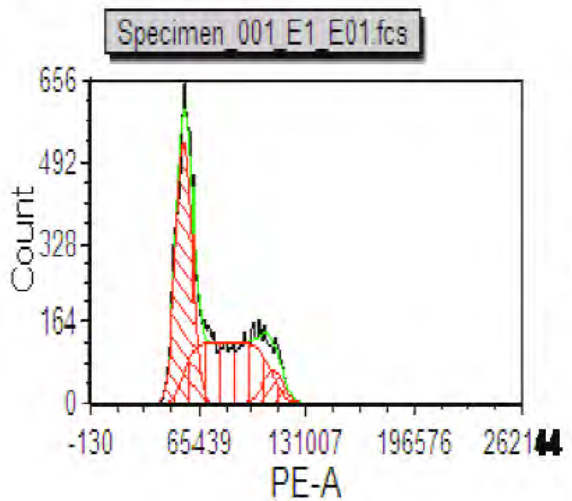

\section{Interpretation}

MultiCycle suggestions (a guideline only):

No abnormal DNA content is observed.

The diploid $\% \mathrm{~S}=47.2, \% \mathrm{G} 2=7.69$

The $S$ Phase confidence is good

\section{Experiment Statistics}

Chi sq: 2.23

Number of cells: 13838.00

Number of cycles: 1.00

Cycle fit model: 1 Cycle

B
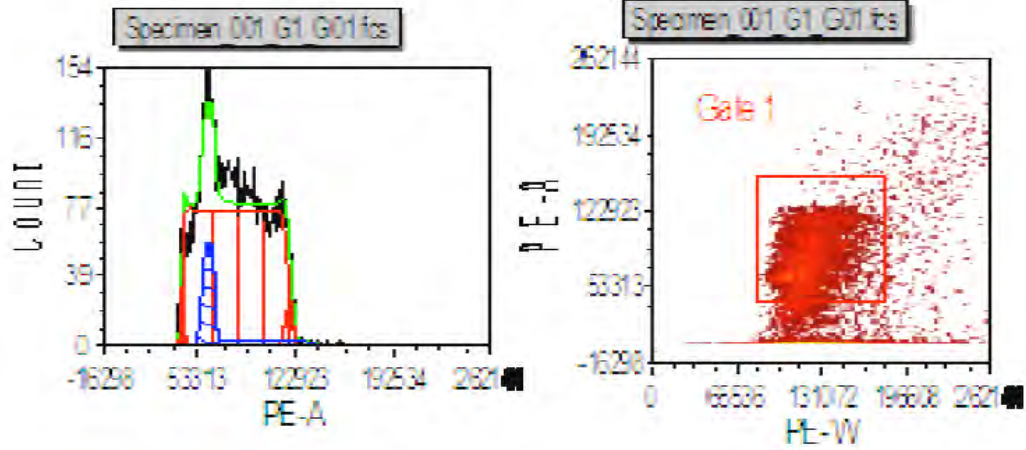

Interpretation

WutOpe sugestoors (a guideine ony): An aneupoid DNA content is obseried.

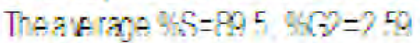

The S Phese confideroe is good

\section{Experiment Statistics}

Chisq: 273

Averoge 76.80 .54

Average 9.8 aneupoid: 36.25

$\mathrm{BA}[\mathrm{b} 1.17$

Nenter of cels: $63 t .00$

Ninter of oydes. 200

Oyde it nodet 20 ode
C

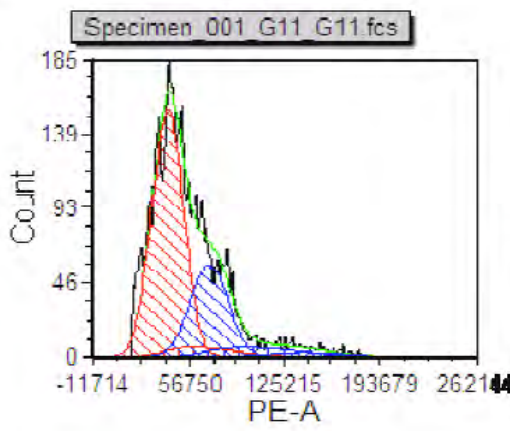

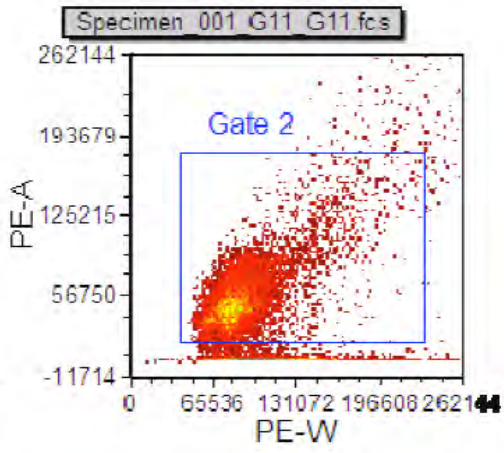

\section{Interpretation}

MultiCvcle suggestions (a quideline onlv): An aneuploid DNA content is observed.

The average $\% \mathrm{~S}=11.4, \% \mathrm{G} 2=2.38$

The $S$ Phase confidence is good

\section{Experiment Statistics}

Chi sq: 4.16

Average \%s: 11.40

Average $\%$ s aneuploid: 17.74

BAD: 0.00

Number of cells: 7051.00

Number of cycles: 2.00

Cycle fit model: 2 Cycle 
(Figure 5). Continued

D
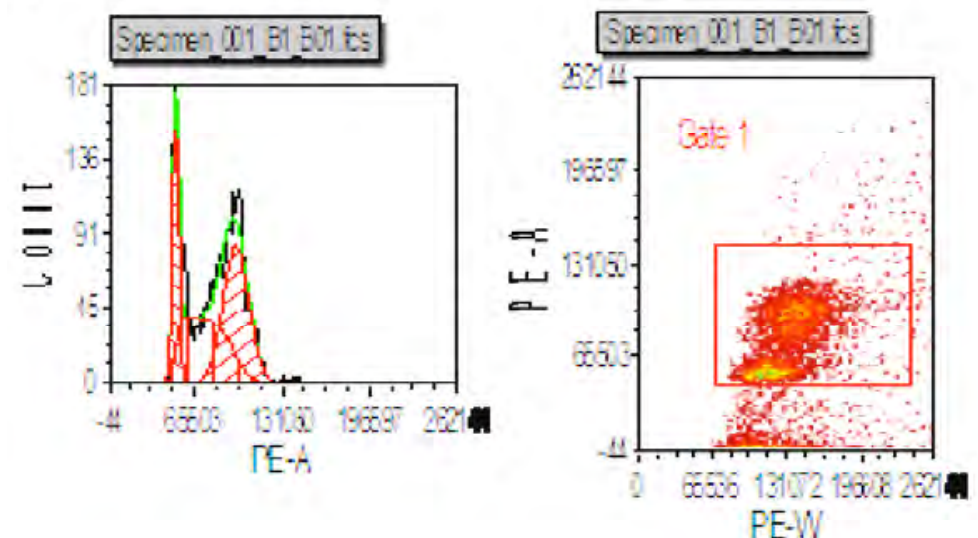

Interpretation

MtCyce sugestions (a guideine ont)

No abornal DNA content is coserved.

The diplad \% $\$=36.1, \% G 2=4 \$ 1$

The S Prase confidence is fail

Nob: inter-model arror.

Experiment Statistics

Chiso: 1.90

BAD 0.00

Nunter of cels: 4022.00

Ninter of oydes. 1.00

Gode it model 1 Oyde

E
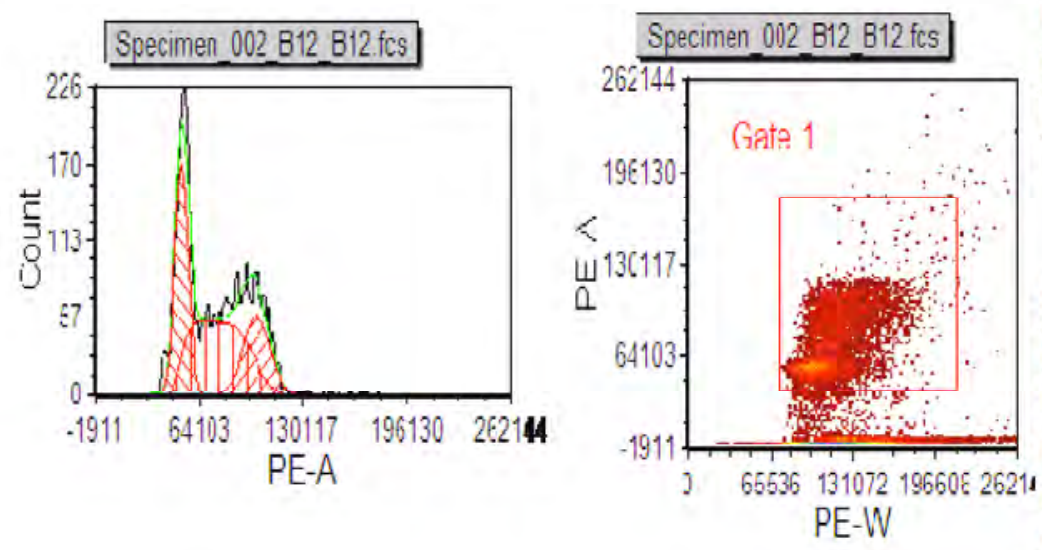

\section{Interpretation}

MultiCycle suggestions (a guideline only'):

No abnormal DNA content is observed.

The dicloid $\% \mathrm{~S}=46,8, \% \mathrm{G} 2=22.1$

The S Phase confidence is good

\section{Experiment Statistics}

Chisq: 1.58

BAD: 0.00

Number of cells: 5557.00

PE-W

Number of sycles 100

Cycle fit rrodel: 1 Cycle

Figure 5: Flow cytometry diagrams showing cell cycle progression function of type of UV irradiation and Crataegus monogyna extract treatment: A) un-exposed cell control; B) UVB irradiated cells; C) UVB irradiated cells treated with Crataegus extract (Dermo-P), D) UVA irradiated cells, E) UVA irradiated cells treated with Crataegus extract (Dermo-P).

Table 6: Cell Cycle Distribution after UV Radiation and Crataegus monogyna Extract Treatment

\begin{tabular}{|c|c|c|c|c|c|c|c|c|c|c|}
\hline \multirow{4}{*}{$\begin{array}{l}\text { Tested } \\
\text { compound }\end{array}$} & \multicolumn{4}{|c|}{$\mathbf{S} \%$} & \multicolumn{4}{|c|}{ G2/M \% } & \multicolumn{2}{|c|}{ S+G2/M\% } \\
\hline & \multirow{3}{*}{$\begin{array}{c}\text { Not } \\
\text { irradiated }\end{array}$} & \multirow{3}{*}{$\begin{array}{c}\text { UVA } \\
\text { irradiation }\end{array}$} & \multicolumn{2}{|c|}{ UVB irradiation } & \multirow{3}{*}{$\begin{array}{c}\text { Not } \\
\text { irradiated }\end{array}$} & \multirow{3}{*}{$\begin{array}{l}\text { UVA } \\
\text { irradiation }\end{array}$} & \multicolumn{2}{|c|}{ UVB irradiation } & \multirow{3}{*}{$\begin{array}{c}\text { Not } \\
\text { irradiated }\end{array}$} & \multirow{3}{*}{$\begin{array}{l}\text { UVA } \\
\text { irradiation }\end{array}$} \\
\hline & & & diploid & aneuploid & & & & & & \\
\hline & & & & & & & diploid & aneuploid & & \\
\hline Cellular control & $47.10 \pm 1.05$ & $35.63 \pm 2.8$ & $83.17 \pm 2.3$ & $32.38 \pm 3.5$ & $7.42 \pm 1.06$ & $39.07 \pm 4.4$ & $1.92 \pm 0.9$ & 0 & $54.5 \pm 0.9$ & $47.7 \pm 1.9$ \\
\hline Solvent control & $49.73 \pm 1.16$ & $33.77 \pm 2.06$ & $81.6 \pm 0.7$ & $25.1 \pm 2.6$ & $4.58 \pm 1.01$ & $29.87 \pm 3.44$ & $1.04 \pm 0.4$ & 0 & $54.5 \pm 1.03$ & $63.6 \pm 0.8$ \\
\hline $\begin{array}{c}\text { Crataegus } \\
\text { monogyna extract } \\
1 / 2000(\mathrm{v}: \mathrm{v})\end{array}$ & $37.70 \pm 2.16$ & $30.17 \pm 2.06$ & $51 \pm 3.9$ & $12.48 \pm 0.6$ & 0 & $16.17 \pm 1.53$ & $0.75 \pm 0.02$ & 0 & $37.7 \pm 1.1$ & $46.3 \pm 1.2$ \\
\hline $\begin{array}{c}\text { Crataegus } \\
\text { monogyna extract } \\
1 / 4000(\mathrm{v}: \mathrm{v})\end{array}$ & $41.27 \pm 30.1$ & $43.70 \pm 2.88$ & $62.90 \pm 3.5$ & $15.37 \pm 2.9$ & 0 & $21.5 \pm 5.62$ & $5.38 \pm 1.2$ & 0 & $41.3 \pm 1.2$ & $65.2 \pm 1.5$ \\
\hline
\end{tabular}




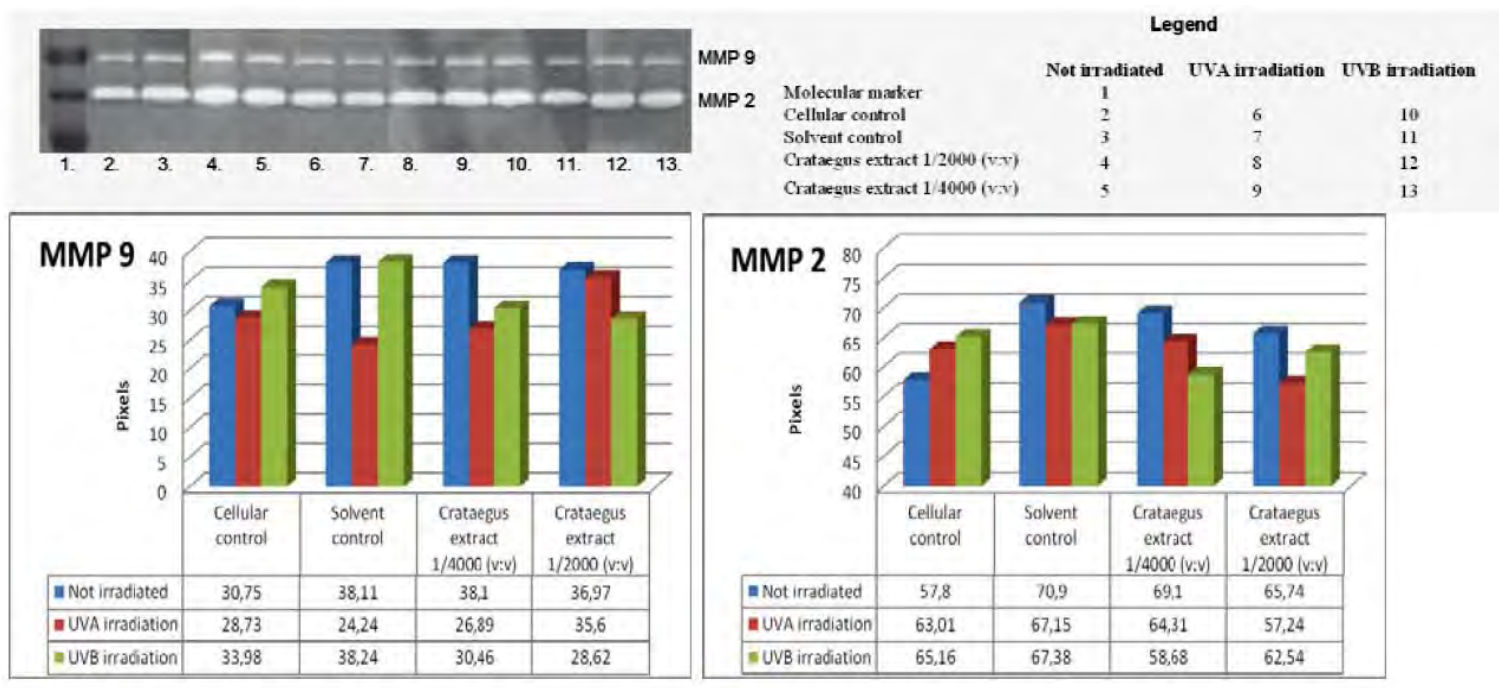

Figure 6: Gelatin substrate gel zymography demonstrating MMP-2 and MMP-9 activity from HaCaT keratinocyte culture media.

causes an augmentation of $\mathrm{G} 2 / \mathrm{M}$ phase, and consequently an acceleration of mithosis and an aberrant proliferation of damaged cells. After UVB exposure the cell cycle is arrested in S phase, leading to one of the first tumorigenic effect, the aneuploidy, due to the alteration of normal mitotic checkpoints (Figure 5). Our data suggest that $C$. monogyna extract can suppress the "in vitro" premalignant conversion of UVB irradiated normal human keratinocytes, especially reducing the percent of aneuploidy (Figure 5 and Table 6). As well as, in UVA irradiated keratinocytes, the bioactive compounds from the extract reduce the cellular percent in G2/M check-point, that prevent the entrance of UV-damaged cells in mithosis, avoiding their aberrant proliferation.

\section{Crataegus monogyna Action on Extracellular Matrix Recovery after UV Radiation}

Two bands of gelatinolysis, $92 \mathrm{kDa}$ and $72 \mathrm{kDa}$ were detected in the culture medium from HaCaT cells exposed / un-exposed to UV radiation, showing different effects on MMP-9 and MMP-2 expression. The gelatinolytic activity of MMP-2 was remarkably downregulated in the experimental systems treated $72 \mathrm{~h}$ with C. monogyna dilutions (1/2000 v:v and $1 / 4000 \mathrm{v}: \mathrm{v})$, whereas MMP-9 was almost the same with solvent control for un-exposed cells, down-regulated for UVB iradiation, but stimulated after UVA exposure for $1 / 2000$ (v:v) dos

\section{CONCLUSIONS}

Correlative methods of investigation composing the screening of patho-biological mechanisms induced by UV radiation are necessary for the identification of the right cellular / molecular target of a new photoprotective agent. C. monogyna extract with a rich content of pro-antocians, flavones and polyphenolcarboxylic acids, exert a strong UVA and UVB action on intracellular oxygen reactive species through the activation of the enzymatic system involved in their transformation and inactivation. It also has an anti-inflammatory action on IL8 pathways in UV-A and UV-B irradiation conditions, but inhibits IL6 release only after UVA exposure. The rising of IL $1 \alpha$ recommend the use of the extract only avoiding direct sun exposure (night treatment formulations). The extract acts on the extracellular matrix recovery, both after UVA and UVB irradiation, inhibiting differentiated MMP9 and MMP2 respectively and induce cellular protection against apoptosis only at UVA exposure. Another important UV-protective effect is its action on cell cycle progression, normalizing the alteration of normal mitotic checkpoints leading to aberrant proliferation and aneuploidy. All these data sustain $C$. monogyna extract as an active ingredient mostly for UVA photo-damages treatment than for solar burns induced by UVB.

\section{ACKNOWLEDGEMENT}

This work had financial assistance from POS CCE ID 383 SMIS CSNR 6009 CTR 107/2010 - DERMOLAB "International standards implementation for the organization of a dermato-cosmetic research and testing core".

\section{REFERENCES}

[1] Clydesdale GJ, Dandie GW, Muller KH. Ultraviolet light induced injury: Immunological and inflammatory effects. Immunol Cell Biol 2001; 79: 547-68. http://dx.doi.org/10.1046/j.1440-1711.2001.01047.x 
[2] Sesto A, Navarro M, Burslem F, Jorcano JL. Analysis of the ultraviolet $\mathrm{B}$ response in primary human keratinocytes using oligonucleotide microarrays. PNAS 2002; 99(5): 2965-70. http://dx.doi:10.1073/pnas.052678999

[3] Hanson KM, Clegg RM. Observation and Quantification of Ultraviolet-induced Reactive Oxygen Species in Ex Vivo Human Skin. Photochem Photobiol 2002; 76 (1): 57-63. http://dx.doi:10.1562/00318655(2002)07600570AQOUI2.0.CO2

[4] Petersen AB, Gniadecki R, Vicanova J, Thorn T, Wulf HC. Hydrogen peroxide is responsible for UVA-induced DNA damage measured by alkaline comet assay in $\mathrm{HaCaT}$ keratinocytes. J Photochem Photobiol B 2000; 59(1-3): 12331. http://dx.doi.org/10.1016/S1011-1344(00)00149-4

[5] Fisher GJ, Datta SC, Talwar HS, Wang ZQ, Varani J et al. Molecular basis of sun-induced premature skin ageing and retinoid antagonism. Nature 1996; 379(6563): 335-9. http://dx.doi:10.1038/379335a0

[6] Varani J, Spearman D, Perone P, et al. Inhibition of type I procollagen synthesis by damaged collagen in photo aged skin and by collagenase-degraded collagen in vitro. Am J Pathol 2001; 158: 931-42.

[7] Wlaschek M, Heinen G, Poswig A, et al. UVA-induced autocrine stimulation of fibroblast-derived collagenase/MMP1 by interrelated loops of interleukin-1 and interleukin-6. Photochem Photobiol 1994, 59(5): 550-6. http://dx.doi:10.1111/j.1751-1097.1994.tb02982.x

[8] Fisher GJ, Wang ZQ, Datta SC, et al. Pathophysiology of premature skin aging induced by ultraviolet light. New Eng $\mathrm{J}$ Med 1997; 337: 1419-28.

[9] Schwarz T, Luger TA. New trends in photobiology: Effect of UV irradiation on epidermal cell cytokine production. J Photochem Photobiol B: Biology 1989; 4(1): 1-13. http://dx.doi.org/10.1016/1011-1344(89)80097-1

[10] Ananthaswamy HN, Pierceall WE. Molecular mechanisms of ultraviolet radiation carcinogenesis; Photochem Photobiol 1990; 52(6): 1119-36.

http://dx.doi:10.1111/j.1751-1097.1990.tb08452.x

[11] Kulms D, Schwarz T. Molecular mechanisms of UV-induced apoptosis. Photodermatol. Photoimmunol Photomed 2000; 16: 195-201.

[12] DiPaola RS. To Arrest or Not To G2-M Cell-Cycle Arrest. Clin Cancer Res 2002; 8: 3311-4.

[13] Weller EMO, Hain J, Jung T, et al. UV-B-induced cell cycle perturbations, micronucleus induction, and modulation by caffeine in human keratinocytes. Int J Radiat Biol 1996; 69: 371-84.

[14] Pastila $R$, Leszczynski D. Ultraviolet-A radiation induces changes in cyclin $G$ gene expression in mouse melanoma B16-F1 cells. Cancer Cell Int 2007; 7: 7.

http://dx.doi:10.1186/1475-2867-7-7

[15] Lee YS, Jin D-Q, Beak S-M, Lee E-S, Kim J-A. Inhibition of ultraviolet-A-modulated signaling pathways by asiatic acid and ursolic acid in HaCaT human keratinocytes. Eur J Pharmacol 2003; 476: 1738.http://dx.doi.org/10.1016/S0014-2999(03)02177-0

[16] F Vicentini TMC, Tianyuan He, Fonseca MJV, et al. Quercetin inhibits UV irradiation-induced inflammatory cytokine production in primary human keratinocytes by suppressing NF-KB pathway. J Dermatol Sci 2011; 61(3): 162-8.

http://dx.doi.org/10.1016/j.jdermsci.2011.01.002

[17] Wu S, Gao J, Dinh QT, Chen C, Fimmel S. IL-8 production and AP-1 transactivation induced by UVA in human keratinocytes: roles of D-alpha-tocopherol. Mol Immunol 2008; 45: 2288-96.

[18] Miller NJ, Rice-Evans C, Davies MJ, Gopinathan V, Milner A A novel method for measuring antioxidant capacity and its application to monitoring the antioxidant status in premature neonates. Clin Sci 1993; 84: 407-12.

[19] Choi DW, Leininger-Muller B, King YC, et al. Differential role of CYP2E1 Binders and Isoniazid on CYP2E1 Protein Modification in NADPH-dependent Microsomal Oxidative Reactions: Free Radical Scavenging Ability of Isoniazid. Free Radical Res 2002; 36: 893-903. http://dx.doi.org/10.1080/10715760260055249

[20] Si Eun Lee, Hwang HJ, Kim JH. Screening of medicinal plant extracts for antioxidant activity. Life Sci 2003; 73: 167-79. http://dx.doi.org/10.1016/S0024-3205(03)00259-5

[21] Barltrop JA, Oven TC, Cory AH, Cory GJ. 5-(3carboxymethoxyphenyl)-2-(4,5-dimenthylthiazoly)-3-(4-

sulfophenyl)tetrazolium, inner salt (MTS) and related analogs of 3-(4,5-dimethylthiazolyl)-2,5-diphenyltetrazolium bromide (MTT) reducing to purple water-soluble formazans as cellviability indicators. Bioorg Med Chem Lett 1991; 1: 611-4. http://dx.doi.org/10.1016/S0960-894X(01)81162-8

[22] Riss TL, Moravec RA. Comparison of MTT, XTT, and a novel tetrazolium compound for MTS for in vitro proliferation and hemosensitivity assays. Mol Biol Cell 1992; 3(Suppl.): 184a.

[23] Allen MJ, Rushton N. Use of the CytoTox 96 ${ }^{\mathrm{TM}}$ Assay in routine biocompatibility testing in vitro. Promega Notes 1994; 45: 7-10.

[24] Carini M, Aldini G, Piccone M, Facino RM. Fluorescent probes as markers of oxidative stress in keratinocyte cell lines following UVB exposure. II Farmaco 2000; 55: 526-34. http://dx.doi.org/10.1016/S0014-827X(00)00037-9

[25] Robinson JP. Current Protocols in Cytometry. vol 2, Unit 9.7, 9.7.1 - 9.7.14, Ed. John Wiley \&Sons. 2009.

[26] http://www.sigmaaldrich.com/technicaldocuments/protocols/biology/enzymatic-assay-of-superoxidedismutase.html

[27] AEBI HE, Catalase in Bergmeyer, HU, Methods in enzymatic analysis., Weinheim: Verlag Chemie, 1978; 273-286.

[28] Tornier C, Rosdy M, Maibach HI. In vitro skin irritation testing on reconstituted human epidermis: Reproducibility for 50 chemicals tested with two protocols. Toxicol In vitro 2006; 20 : 401-6.

[29] Cook EB, Stahl JL, Lowe L, et al. Simultaneous measurement of six cytokines in a single sample of human tears using microparticle-based flow cytometry: allergics vs non-allergics. J Immunol Methods 2001; 254: 109-18. http://dx.doi.org/10.1016/S0022-1759(01)00407-0

[30] Herron GS, Werb Z, Dwyer K, Banda MJ. Secretion of metalloproteinases by stimulated capillary endothelial cells. II. Expression of collagenase and stromelysin activities is regulated by endogenous inhibitors. J Biol Chem 1986; 261: 2814-9.

Received on 06-06-2012 Accepted on 17-08-2012

Published on 19-09-2012

\section{DOI: http://dx.doi.org/10.6000/1927-3037/2012.01.03.04}

(c) 2012 Dumitriu et al.; Licensee Lifescience Global.

This is an open access article licensed under the terms of the Creative Commons Attribution Non-Commercial License (http://creativecommons.org/licenses/by-nc/3.0/) which permits unrestricted, non-commercial use, distribution and reproduction in any medium, provided the work is properly cited. 